\title{
Androgen Receptor Expression and Sperm Function in Male Infertility
}

\author{
Adel A. Zalata ${ }^{1}$, Naglaa Mokhtar ${ }^{1}$, Gamal Othman ${ }^{1}$, \\ Abd EL-Naser Badawy ${ }^{1}$ Moheiddin Alghobary ${ }^{2}$ and ${ }^{3}$ Amal A. Aziz \\ ${ }^{1}$ Medical Biochemistry and, ${ }^{2}$ Dermatology, Venereology and Andrology \\ Departments, Faculty of Medicine, Mansoura university ${ }^{3}$ Clinical Pathology \\ Department, Faculty of Medicine, Cairo University
}

\begin{abstract}
The androgen receptor (AR), a member of the nuclear receptor superfamily, plays important role in male reproductive functions. A functional androgen receptor is required for male embryonic sexual differentiation, pubertal development and regulation of spermatogenesis. The role of AR during spermatogenesis has been the subject of intense interest for many years. Several reports have shown that AR function is required for the completion of meiosis and the transition of spermatocytes to haploid round spermatids. The aim of the present study was to determine the association between androgen receptor expression and fertilization ability of human sperm in different andrological diseases. Eighty semen samples obtained from men attending the Andrology Outpatient Clinic, Mansoura University Hospital were included in the study. The samples were grouped into control $(n=20)$, accessory sex gland inflammation (MAGI) $(n=18)$, varicocele $(n=25)$ and idiopathic infertility $(n=17)$. The semen samples analyses were done according to the recommendation of the World Health Organization. Computer assisted semen analysis (Autosperm) was performed. The acrosome reaction of spermatozoa recovered from each sample was assessed before and after stimulation with the calcium ionophore A23187 (Sigma, St. Louis, Missouri, USA) by the pisum sativum (Sigma, St. Louis, Missouri, USA) fluorescence method with simultaneous vitality stain (Hoechst 33258, Germany). RNA was extracted from sperm of all cases and controls. cDNA and amplification of a gene region from 1648 to 2055 bp corresponding to the DNA binding domain plus the hinge region of human androgen receptor was carried out by one step RT-PCR. The PCR product size of $400 \mathrm{bp}$ was electrophoresed on agarose gel 2\% electrophoresis. Androgen receptor expression was significantly decreased in MAGI, varicocele and idiopathic groups compared with the control $(P<0.01)$. Furthermore, $A R$ expression was positively correlated with grade $A+B$ motility $(r=0.476$, $P<0.0001$, velocity $(r=0.362, P<0.001)$, linear velocity $(r=0.454, P<0.0001), \alpha-$ glucosidase $(r=0.420, P<0.0001)$ and acrosome reaction $(r=0.532, P<0.0001)$.
\end{abstract}

\section{INTRODUCTION}

Androgens and the androgen receptor (AR) play important roles in male fertility ${ }^{(1)}$. The local actions of androgen on testis functions were initially demonstrated when testosterone alone, in the absence of the gonadotropins, leuteinizing hormone (LH), and follicle- 
stimulating hormone (FSH), could support spermatogenesis ${ }^{(2)}$. Furthermore, AR has been detected in Sertoli, Leydig, peritubular myoid cells, and spermatid cells (round and elongated $)^{(3)}$. Androgens, by signaling through the androgen receptor (AR), mediate a wide range of physiological responses and developmental processes, involving both reproductive and non reproductive systems in the male ${ }^{(4)}$. The androgen receptor, a member of the nuclear receptor superfamily, plays important roles in male reproductive functions ${ }^{(5)}$.

The androgen receptor which encoded by a single-copy gene located in the long arm of the X chromosome (Xq11-12); is a member of the nuclear receptor superfamily and acts as a ligand-inducible transcription factor to modulate expression of target genes ${ }^{(6)}$.The AR gene comprises eight exons that encode a $110 \mathrm{kDa}$ protein, which contains an N-terminal transactivation domain, a central DNA-binding domain, and a C-terminal ligandbinding domain. Testosterone and its more potent metabolite, dihydrotestosterone can bind $\mathrm{AR}$, and the ligand AR form homodimers and interact with many coregulators to modulate androgen target genes ${ }^{(7)}$.

AR also, has dual post-meiotic roles during male germ cell differentiation, which consists of terminal differentiation of spermatids and their release from the seminiferous epithelium. Further, progression of spermatids to elongation steps is sensitive to Sertoli cell AR function ${ }^{(6)}$. There is a general agreement that AR can be detected in Sertoli cells and cells in the interstitial spaces including Leydig cells and perivascular smooth muscle cells in testis ${ }^{(8)}$. AR has been also detected in peritubular myoid and spermatid cells (round and elongated) ${ }^{(\mathbf{9})}$.Using antibody staining, the localization of the AR in male germ cells remains controversial. Several studies indicated that $\mathrm{AR}$ is present in germ cells in different species ${ }^{(\mathbf{1 0})}$, but other reports show that there is no $\mathrm{AR}$ staining in the germ cells ${ }^{(11)}$.

The presence of AR in human sperm was demonstrated by western blot and immune-fluorescence assay (10). Also, Aquila et al. (12) demonstrated that ARs is present in human sperm at different levels. A gene region corresponding to the DNA binding domain plus the hinge region of the human AR was amplified and the product was sequenced and found to be identical to the classical human AR.

AR dysfunction causes a diverse range of clinical disorders, such as testicular feminization mutation (Tfm) syndrome, prostate cancer, and Kennedy's disease. Failure of the mutated receptor to activate its target genes causes a spectrum of hereditary disorders of androgen insensitivity syndrome (AIS) or testicular feminization (Tfm) mutation ${ }^{(13)}$. In less severe cases, where some level of androgen responsiveness is maintained, there are a wide range of phenotypes.

The aim of the present study was to determine the association between androgen receptor expression and fertilization ability of human sperm in different andrological diseases. 


\section{SUBJECTS \& METHODS}

Eighty semen samples obtained from men attending the Andrology Outpatient Clinic, Mansoura University Hospital were included in the study. The samples were grouped into control $(n=20)$, accessory sex gland inflammation (MAGI) $(\mathrm{n}=18)$, varicocele $(n=25)$ and idiopathic infertility $(n=17)$. All specimens were collected by masturbation after an abstinence period of 48-72 $\mathrm{h}$ and allowed to liquefy completely for 15 $30 \mathrm{~min}$. at $37^{\circ} \mathrm{C}$.

Semen Analysis: After complete liquefaction, semen samples were analyzed for sperm concentration, motility, and viability according to WHO guidelines (14). Computer assisted semen analysis by Autosperm (Fertipro, Belgium) ${ }^{(\mathbf{1 5 )}}$ was performed. Sperm morphology was evaluated by phase contrast microscope and sperm Mac stain (Fertipro, Belgium). Peroxidase positive white blood cells (WBCs) were detected By Peroxidase stain (16). Seminal plasma was obtained by centrifugation of the semen sample and analyzed for $\alpha$ glucosidase activity by the method described by Guerin et al. ${ }^{(17)}$.The acrosome reaction of spermatozoa recovered from each sample was assessed before and after stimulation with the calcium ionophore A23187 (Sigma, St. Louis, Missouri, USA) by the pisum sativum (Sigma, St. Louis, Missouri, USA) fluorescence method with simultaneous vitality stain (Hoechst 33258, Germany).

Spermatozoa were isolated from pooled normal semen samples by centrifugation on a discontinuous Percoll density gradient (80:40, vol./vol.) ${ }^{(14)}$. After centrifugation for $20 \mathrm{~min}$. at $800 \times \mathrm{g}$, the $80 \%$ Percoll fraction was examined using an optical microscope equipped with a100 $\times$ oil objective to ensure that a pure sample of spermatozoa was obtained. The pellet was then washed twice with BSA-free Ham's-F10 medium. After purification, the cells were used immediately for RNA isolation.

Estimation of some blood hormones: Five $\mathrm{ml}$. of blood were withdrawn after an overnight fasting from men included in the study. The sample was used to separate sera for testosterone $(\mathrm{T})$, luteinizing hormone (LH), follicle-stimulated hormone (FSH), estradiol (E2) and prolactin assessment by enzyme linked immunosorbent assay (ELISA).

Total RNA isolation from sperm pellets: Total RNA isolation was done according to the method of Chomczynski (18) using Tri-Fast $^{\mathrm{TM}}$ reagent kit purchased from Peq Lab Biotechnologie GmbH, Germany. Total RNA extraction was carried out from sperm pellet using Tri-Fast ${ }^{\mathrm{TM}}$ reagent (Peq Lab. Biotechnologie $\mathrm{GmbH}$, Carl-Thiersch St. 2B 91052 Erlongen, Germany, Cat. No. 30-2010 according to the manufacturer's instructions. The remaining DNA was removed by digestion with DNase I (Sigma). The concentration of isolated RNA was determined spectrophotometrically by measuring the optical density (OD) at $260 \mathrm{~nm}$ (Jenway, Genova Model, UK). 10 $\mu 1$ of each sample was added to $990 \mu$ of DEPC treated water and quantified by measuring the absorbance at $260 \mathrm{~nm}$ as RNA yield $(\mu \mathrm{g} / \mathrm{ml})=\mathrm{A} 260 \mathrm{X} 40 \mathrm{X}$ 100 (dilution factor) ${ }^{(19)}$. The purity of 
RNA was determined by gel electrophoresis through formaldehyde agarose gel electrophoresis and ethidium bromide staining to show 2 sharp purified bands, these two bands represented $28 \mathrm{~S}$ and $18 \mathrm{~S}$ ribosomal RNA.

Gene specific primers used were: Gene specific primers were purchased from Biolegio. BV, PO Box 91, 5600 AB Nijmegen, Netherlands. The sequence of the oligonucleotide primers of androgen receptor gene were designed according to Gene Bank sequences as follow:

5`TGCCCATTGACTATTACTTTCC -3 (forward primer) and

5 '-TGTCCAGCACACACTACACC3` (reverse primer).

Chosen to amplify the gene region from 1648 to 2055 bp corresponding to the DNA binding domain plus the hinge region of human androgen receptor $^{(\mathbf{1 2})}$. The sequence of the oligonucleotide primers of GAPDH ${ }^{\mathbf{( 2 0 )}}$ were designed according to Gene Bank sequences as follow:

Forward primer 5'-CGG AGT CAA CGG ATT TGG TCG TAT3'.

Reverse primer 5'-AGC CTT CTC CAT GGT GGT GAA GAC3'

Primer preparation: The forward and reverse primes were shipped desalted and lyophilized and prepared by suspension in a sterile double distilled water and vortexed thoroughly. The oligonucleotide primers were stored in the form of aliquots at $-30^{\circ} \mathrm{C}$ until the time of use. At the time of use, stock solution was diluted with a sterile water to reach a concentration of 10picomole/ $\mu 1$.

RT-PCR for extracted RNA: Semiquantitative reverse transcription polymerase chain reaction ( RT-PCR) was performed using Ready-to-Go RT-PCR beads for first cDNA synthesis and PCR reaction provided by Amersham Biosciences, England. Cat. No. 27-9266-01, according to the method of Berchtold et al ${ }^{(21)}$.

Ready-to-Go RT-PCR beads utilize Moloney Murine leukemia virus (MMuLV) reverse transcriptase and Taq polymerase to generate PCR product from RNA template. Each bead is optimized to allow the first strand cDNA synthesis and PCR reaction to proceed sequentially as a single tube, single step reaction. The reaction passed as follow:

A) Synthesis of cDNA: The followings were added to each tube containing the beads: $2 \mu \mathrm{l}$ of first strand primer, provided by the kit, 3 $\mu l$ containing 30 pmol of PCR genespecific primer (forward primer), $3 \mu 1$ containing 30 pmol of PCR genespecific primer (reverse primer), $25 \mu \mathrm{l}$ of total template RNA containing $1 \mu \mathrm{g}$ and $17 \mu \mathrm{l}$ of DEPC-treated water to obtain a total volume of $50 \mu \mathrm{l}$. One tube was prepared as a negative control reaction to test for DNA contamination.

The dehydrated bead (without template and primers) was incubated at $70^{\circ} \mathrm{C}$ for 5 minutes to inactivate the M-MuLV reverse transcriptase. $50 \mu \mathrm{l}$ mineral oil were added to overlay the reaction. The reactions were transferred to the thermal cycler and incubated at $42^{\circ} \mathrm{C}$ for 60 minutes for synthesis of cDNA followed by incubation at $94^{\circ} \mathrm{C}$ for 5 minutes to inactivate the reverse transcriptase and completely denature the template.

B) Amplification of cDNA by PCR: Thermal cycling reaction was performed using thermal cycler 
(TECHANE TC-321, model FTC3102D, UK) with the following program: 40 cycles of denaturation at $95^{\circ} \mathrm{C}$ for 1 minute, annealing at $55^{\circ} \mathrm{C}$ for 1 minute, and extension at $72^{\circ} \mathrm{C}$ for 2 minute then final extension at 72 ${ }^{\circ} \mathrm{C}$ for 10 minutes ${ }^{(\mathbf{1 2})}$.

C)Detection of amplified RT-PCR products: The products was subjected to agarose gel electrophoresis using $2 \%$ agarose stained with ethidium bromide and visualized via light UV Transilluminator (Model TUV-20, OWI. Scientific, Inc. 800 242-5560) and photographed under fixed conditions (the distance, the light and the zoom).

The results were analyzed with scion image ${ }^{\circledR}$ release Alpha 4.0.3.2.software for windows ${ }^{\circledR}$ which performs bands detection and conversion to peaks. Area under each peak were calculated in square pixels and used for quantification. AR gene expression levels were determined by calculating the ratio between the square pixel values of the target bands in relation to the control bands (GAPDH, house keeping gene for RTPCR (Figure1).

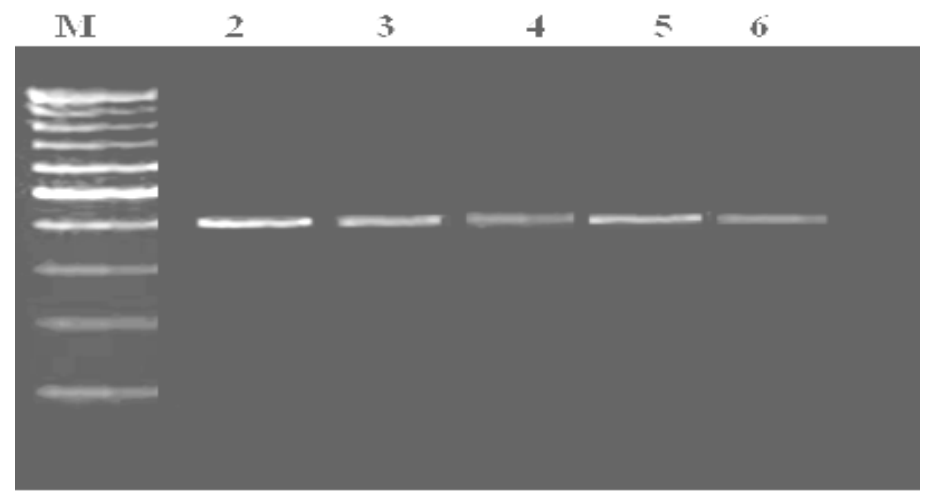

Figure (1): Gel electrophoresis of RT-PCR products of androgen receptor gene in different groups.

Lane 1:molecular weight marker100 bp each, lane 2 represent the expression of the positive control gene GAPDH, lane 3,4,5,6 represent the expression of androgen receptor gene in normal, varicocele, idiopathic and MAGI groups respectively.

\section{Statistical Analysis:}

Statistical analysis was performed using MedCalc ${ }^{\circledR}$ program version 8.1.0.0 ${ }^{(22)}$. The data were expressed as median and range. Mann-Whitney test was used as a test of significance for comparison between two groups. Spearman rank correlation coefficient was done to study the relations between variables. Multiple stepwise regression analysis was done to analyze the relationship between a dependent variable and one or more independent variables. $\mathrm{P}$ values were expressed and considered significant if $<0.05$.

\section{RESULTS}

Semen parameters including semen volume, sperm concentration, grade A motility, grade $\mathrm{A}+\mathrm{B}$ motility, 
velocity, linear velocity, linearity index, normal morphology (\%), white blood cells (WBC), spermatogenic cells and $\alpha$-glucosidase activity of the different groups were shown in table (1).

Table (2) shows that F.S.H levels were significantly increased in varicocele, idiopathic, and in MAGI groups compared with the control group. There was significant decrease in testosterone levels in varicocele, and in MAGI $(\mathrm{P}<0.05)$ groups compared with the control group. The results of the current study showed significant decrease in grade A motility, grade $\mathrm{A}+\mathrm{B}$ motility, linear velocity, linearity index and $\alpha$ glucosidase activity in varicocele, MAGI, and idiopathic groups when compared with the control $(\mathrm{P}<0.0001)$ (table 1). Also, there was significant decrease in acrosome reaction in varicocele, MAGI, and idiopathic groups when compared with the control $(\mathrm{P}<0.001)$ (table 3$)$.

Also, there was significant decrease in acrosome reaction in varicocele, MAGI, and idiopathic groups when compared with the control $(\mathrm{P}<0.001)$ (table 3$)$.

Androgen receptor expression studied by RT-PCR for mRNA was significantly decreased in varicocele, MAGI, and idiopathic groups compared with the control $(\mathrm{P}<0.01)$. (figure 1, table 3).

As regard the correlation between AR expression and some blood hormones, there was significant positive correlation between AR expression and testosterone $(\mathrm{r}=0.246$, $\mathrm{p}=0.0292$ ). Meanwhile, there was significant negative correlation between AR expression and FSH ( $\mathrm{r}=$ $0.307, \mathrm{P}=0.0060)$ and $\mathrm{E}_{2}(\mathrm{r}=-0.300$, $\mathrm{P}=0.0073$ ) (table 4).

Furthermore, AR expression was positively correlated with grade $\mathrm{A}+\mathrm{B}$ motility $(\mathrm{r}=0.476, \quad \mathrm{P}<0.0001$, velocity $(\mathrm{r}=0.362, \mathrm{P}<0.001)$, linear velocity $(\mathrm{r}=0.454, \mathrm{P}<0.0001)$, alpha glucosidase $(\mathrm{r}=0.420, \mathrm{P}<0.0001)$ and acrosome reaction $\quad(\mathrm{r}=0.532$, $\mathrm{P}<0.0001$ ) (table 5). 
Table (1): Semen parameters of all studied groups. Data presented as (median and range).

\begin{tabular}{|c|c|c|c|c|c|}
\hline $\begin{array}{l}\text { Semen } \\
\text { Parameters }\end{array}$ & $\begin{array}{l}\text { Control } \\
\mathrm{n}=\mathbf{2 0}\end{array}$ & $\begin{array}{l}\text { MAGI } \\
n=18\end{array}$ & $\begin{array}{l}\text { Varicocele } \\
\mathrm{n}=\mathbf{2 5}\end{array}$ & $\begin{array}{l}\text { Idiopathic } \\
\mathrm{n}=\mathbf{1 7}\end{array}$ & $\begin{array}{l}\text { Significant } \\
\text { Comparison }\end{array}$ \\
\hline Volume (ml) & $\begin{array}{l}3.9 \\
2-7\end{array}$ & $\begin{array}{l}3.6 \\
1-5\end{array}$ & $\begin{array}{l}4 \\
1-8\end{array}$ & $\begin{array}{l}3.5 \\
1-9\end{array}$ & \\
\hline $\begin{array}{l}\text { Concentration } \\
\text { (million / ml) }\end{array}$ & $\begin{array}{l}70.4 \\
44.8-96.0\end{array}$ & $\begin{array}{l}0.1 \\
0.9-64.0\end{array}$ & $\begin{array}{l}11.1 \\
1.5-54.00\end{array}$ & $\begin{array}{l}27.2 \\
7.5-67.2\end{array}$ & $\begin{array}{l}\mathrm{P}_{1}<0.000 * * * \\
\mathrm{P}_{2}<0.000 * * * \\
\mathrm{P}_{3}<0.000 * * *\end{array}$ \\
\hline Grade motility (\%) & $\begin{array}{l}54.0 \\
41.0-60.0\end{array}$ & $\begin{array}{l}7.5 \\
0.0-38.0\end{array}$ & $\begin{array}{l}5.0 \\
0.0-33.0\end{array}$ & $\begin{array}{l}20.0 \\
0.0-42.0\end{array}$ & $\begin{array}{l}\mathrm{P}_{1}<0.0001 * * * \\
\mathrm{P}_{2}<0.0001 * * * \\
\mathrm{P}_{3}<0.0001 * * *\end{array}$ \\
\hline Grade $\mathrm{A}+\mathrm{B}$ motility (\%) & $\begin{array}{l}61.5 \\
51.0-67.0\end{array}$ & $\begin{array}{l}28.5 \\
2.0-45.0\end{array}$ & $\begin{array}{l}25.0 \\
2.0-42.0\end{array}$ & $\begin{array}{l}30.0 \\
4.0-45.0\end{array}$ & $\begin{array}{l}\mathrm{P}_{1}<0.0001 * * * \\
\mathrm{P}_{2}<0.0001 * * * \\
\mathrm{P}_{3}<0.0001 * * *\end{array}$ \\
\hline Velocity $(\mu \mathrm{m} / \mathrm{sec})$ & $\begin{array}{l}80.0 \\
63.4-95.4\end{array}$ & $\begin{array}{l}41.00 \\
17.8-109.7\end{array}$ & $\begin{array}{l}33.3 \\
8.8-85.3\end{array}$ & $\begin{array}{l}52.9 \\
17.6-81.6\end{array}$ & $\begin{array}{l}\mathrm{P}_{1}<0.0001 * * * \\
\mathrm{P}_{2}<0.0001 * * * \\
\mathrm{P}_{3}<0.0001 * * *\end{array}$ \\
\hline Linear velocity $(\mu \mathrm{m} / \mathrm{sec})$ & $\begin{array}{l}61.0 \\
42.9-70.7\end{array}$ & $\begin{array}{l}22.2 \\
11.2-84.1\end{array}$ & $\begin{array}{l}18.1 \\
5.7-66.2\end{array}$ & $\begin{array}{l}32.5 \\
11.1-53.3\end{array}$ & $\begin{array}{l}\mathrm{P}_{1}<0.0001 * * * \\
\mathrm{P}_{2}<0.0001 * * * \\
\mathrm{P}_{3}<0.0001 * * *\end{array}$ \\
\hline Linearity index $(\mu \mathrm{m} / \mathrm{sec})$ & $\begin{array}{l}78.6 \\
67.5-86.7\end{array}$ & $\begin{array}{l}59.6 \\
33.7-86.5\end{array}$ & $\begin{array}{l}63.0 \\
38.6-97.4\end{array}$ & $\begin{array}{l}62.1 \\
46.4-83.8\end{array}$ & $\begin{array}{l}\mathrm{P}_{1}<0.0001 * * * \\
\mathrm{P}_{2}=0.0037 * * * \\
\mathrm{P}_{3}=0.0001 * * *\end{array}$ \\
\hline Normal morphology (\%) & $\begin{array}{l}64.0 \\
58.0-66.0\end{array}$ & $\begin{array}{l}8.0 \\
0.0-48.0\end{array}$ & $\begin{array}{l}4.0 \\
0.0-44.0\end{array}$ & $\begin{array}{l}12.0 \\
0.0-64.0\end{array}$ & $\begin{array}{l}\mathrm{P}_{1}<0.0001 * * * \\
\mathrm{P}_{2}<0.0001 * * * \\
\mathrm{P}_{3}=0.0001 * * *\end{array}$ \\
\hline WBCs (million / ml) & $\begin{array}{l}0.6 \\
0.4-0.6\end{array}$ & $\begin{array}{l}8.0 \\
0.0-48.0\end{array}$ & $\begin{array}{l}4.0 \\
0.0-44.0\end{array}$ & $\begin{array}{l}12.0 \\
0.0-64.0\end{array}$ & $\begin{array}{l}\mathrm{P}_{1}<0.0001 * * * \\
\mathrm{P}_{2}<0.0001 * * * \\
\mathrm{P}_{3}<0.0001 * * * \\
\end{array}$ \\
\hline $\begin{array}{l}\text { Spermatogenic cells } \\
(\mathrm{million} / \mathrm{ml})\end{array}$ & $\begin{array}{l}2.4 \\
0.4-3.4\end{array}$ & $\begin{array}{l}2.4 \\
1.6-5.6\end{array}$ & $\begin{array}{l}2.4 \\
0.4-6.4\end{array}$ & $\begin{array}{l}2.4 \\
2.4-4.4\end{array}$ & $\begin{array}{l}\mathrm{P}_{1}=0.1284 \\
\mathrm{P}_{2}=0.2741 \\
\mathrm{P}_{3}=0.0137 *\end{array}$ \\
\hline $\begin{array}{l}\text { A- } \alpha \text {-glucosidase } \\
(\mathrm{m} \mathrm{U} / \mathrm{ml}):\end{array}$ & $\begin{array}{l}64.5 \\
45.4-90.7\end{array}$ & $\begin{array}{l}32.9 \\
21.5-44.6\end{array}$ & $\begin{array}{l}26.4 \\
18.4-50.4\end{array}$ & $\begin{array}{l}36.4 \\
18.4-50.6\end{array}$ & $\begin{array}{l}\mathrm{P}_{1}<0.0001 * * * \\
\mathrm{P}_{2}<0.0001 * * * \\
\mathrm{P}_{3}<0.0001 * * *\end{array}$ \\
\hline
\end{tabular}

(a) comparison between control and Varicocele groups., P3= Significant comparison between control and Idiopathic groups. 
Table (2): Blood Hormones of all studied groups.. Data presented as (median and range).

\begin{tabular}{|c|c|c|c|c|c|}
\hline Blood hormone & $\begin{array}{l}\text { Control } \\
\mathrm{n}=20\end{array}$ & $\begin{array}{l}\text { MAGI } \\
\mathrm{n}=18\end{array}$ & $\begin{array}{l}\text { Varicocele } \\
\mathrm{n}=25\end{array}$ & $\begin{array}{l}\text { Idiopathic } \\
\mathrm{n}=17\end{array}$ & $\begin{array}{l}\text { Significant } \\
\text { comparison }\end{array}$ \\
\hline $\begin{array}{l}\text { F.S.H (mIU/ml.): } \\
\text { Median } \\
\text { Range }\end{array}$ & $\begin{array}{l}5.4 \\
3.8-7.1\end{array}$ & $\begin{array}{l}7.4 \\
5.2-18.4\end{array}$ & $\begin{array}{l}9.5 \\
4.5-22.0\end{array}$ & $\begin{array}{l}7.4 \\
5.3-19.0\end{array}$ & $\begin{array}{l}\mathrm{P}_{1}=0.0004 * * * \\
\mathrm{P}_{2}<0.0001 * * * \\
\mathrm{P}_{3}=0.0001 * * *\end{array}$ \\
\hline $\begin{array}{l}\text { LH (mIU/ml.): } \\
\text { Median } \\
\text { Range }\end{array}$ & $\begin{array}{l}6.4 \\
3.4-9.3\end{array}$ & $\begin{array}{l}5.7 \\
3.6-7.5\end{array}$ & $\begin{array}{l}6.4 \\
3.0-8.9\end{array}$ & $\begin{array}{l}6.3 \\
3.4-12.4\end{array}$ & $\begin{array}{l}\mathrm{P}_{1}=0.2993 \\
\mathrm{P}_{2}=0.5757 \\
\mathrm{P}_{3}=0.8192\end{array}$ \\
\hline $\begin{array}{l}\text { Prolactin (ng/ml.): } \\
\text { Median } \\
\text { Range }\end{array}$ & $\begin{array}{l}6.1 \\
3.5-8.6\end{array}$ & $\begin{array}{l}6.2 \\
2.5-11.3\end{array}$ & $\begin{array}{l}7.9 \\
3.9-12.5\end{array}$ & $\begin{array}{l}4.8 \\
2.3-10.8\end{array}$ & $\begin{array}{l}\mathrm{P}_{1}=0.2926 \\
\mathrm{P}_{2}=0.0155^{*} \\
\mathrm{P}_{3}=0.5938\end{array}$ \\
\hline $\begin{array}{l}\text { Estradiol (pg/ml.) } \\
\text { Median } \\
\text { Range }\end{array}$ & $\begin{array}{l}32.5 \\
24.0-45.1\end{array}$ & $\begin{array}{l}36.5 \\
20.2-56.4\end{array}$ & $\begin{array}{l}38.7 \\
20.4-53.1\end{array}$ & $\begin{array}{l}29.6 \\
22.6-44.1\end{array}$ & $\begin{array}{l}P_{1}=0.0655 \\
P_{2}=0.0643 \\
P_{3}=0.0908\end{array}$ \\
\hline $\begin{array}{l}\text { Testosterone } \\
(\mathrm{ng} / \mathrm{ml} .) \text { : } \\
\text { Median } \\
\text { Range }\end{array}$ & $\begin{array}{l}8.9 \\
5.7-11.1\end{array}$ & $\begin{array}{l}7.4 \\
3.8-10.7\end{array}$ & $\begin{array}{l}5.9 \\
3.3-12.0\end{array}$ & $\begin{array}{l}8.4 \\
3.2-12.5\end{array}$ & $\begin{array}{l}\mathrm{P}_{1}=0.0026^{* *} \\
\mathrm{P}_{2}=0.0002 * * * \\
\mathrm{P}_{3}=0.1354\end{array}$ \\
\hline
\end{tabular}

* Significant

** Moderately significant

$* * *$ Highly significant

$\mathrm{P}_{1}=$ Significant comparison between control and MAGI groups., $\mathrm{P}_{2}=$ Significant comparison between control and Varicocele groups., $\mathrm{P}_{3}=$ Significant comparison between control and Idiopathic groups.

Table (3): AR expression and acrosome reaction in all studied groups, (median and range).

\begin{tabular}{|l|l|l|l|l|l|}
\hline Variable & $\begin{array}{l}\text { Control } \\
\mathbf{n = 1 7}\end{array}$ & $\begin{array}{l}\text { MAGI } \\
\mathbf{n = 1 5}\end{array}$ & $\begin{array}{l}\text { Varicocele } \\
\mathbf{n = 2 0}\end{array}$ & $\begin{array}{l}\text { Idiopathic } \\
\mathbf{n = 1 6}\end{array}$ & $\begin{array}{l}\text { Significant } \\
\text { comparison }\end{array}$ \\
\hline $\begin{array}{l}\text { AR } \\
\text { expression }\end{array}$ & 1.0 & 0.5 & 0.7 & 0.8 & $\begin{array}{l}\mathrm{P}_{1}<0.000 * * * \\
\mathrm{P}_{2}<0.000 * * * \\
\mathrm{P}_{3}=0.0329 *\end{array}$ \\
\hline $\begin{array}{l}\text { Acrosome } \\
\text { reaction }\end{array}$ & $0.6-1.5$ & $0.3-0.8$ & $0.5-1$ & $0.1-1.3$ & $\begin{array}{l}\mathrm{P}_{1}<0.000 * * * \\
\mathrm{P}_{2}<0.000 * * * \\
\mathrm{P}_{3}<0.000 * * *\end{array}$ \\
\hline
\end{tabular}

* Significant ** Moderately significant $* * *$ Highly significant

$\mathrm{P}_{1}=$ Significant comparison between control and MAGI groups.

$\mathrm{P}_{2}=$ Significant comparison between control and Varicocele groups.

$\mathrm{P}_{3}=$ Significant comparison between control and Idiopathic groups. 
Table (4): Correlation of AR-expression with blood hormones of all studied groups.

\begin{tabular}{|l|l|l|}
\hline Variable & \multicolumn{2}{|l|}{ AR-expression } \\
\hline & $\mathrm{r}$ & $\mathrm{P}$ \\
\hline LH (mIU/ml.): & 0.0300 & 0.7933 \\
\hline F.S.H (mIU/ml.): & -0.307 & 0.0060 \\
\hline Prolactin (ng/ml.): & -0.0425 & 0.7102 \\
\hline Testosterone (ng/dl.): & 0.246 & 0.0292 \\
\hline $\mathrm{E}_{2}$ (n g/ml.): & -0.300 & 0.0073 \\
\hline
\end{tabular}

- $\mathrm{r}=$ Correlation Coefficient $\quad-\mathrm{P}<0.05=$ significance

Table (5): Correlation of AR-expression with semen characters of all studied groups.

\begin{tabular}{|l|l|l|}
\hline Variable & AR-expression \\
\hline & $\mathrm{r}$ & $\mathrm{P}$ \\
\hline Concentration (million / ml) : & 0.382 & $=0.0005$ \\
\hline Grade A motility $(\%):$ & 0.489 & $<0.0001$ \\
\hline Grade A+B motility $(\%):$ & 0.476 & $<0.0001$ \\
\hline Velocity $(\mu \mathrm{m} / \mathrm{sec}):$ & 0.362 & $=0.0011$ \\
\hline Linear velocity $(\mu \mathrm{m} / \mathrm{sec}):$ & 0.454 & $<0.0001$ \\
\hline Linearity index $(\mu \mathrm{m} / \mathrm{sec}):$ & 0.321 & $=0.0039$ \\
\hline Normal morphology $(\%):$ & 0.470 & $<0.0001$ \\
\hline WBCs $($ million $/ \mathrm{ml}):$. & -0.390 & $=0.0004$ \\
\hline$\alpha$-glucosidase $(\mathrm{m} \mathrm{U} / \mathrm{ml}):$. & 0.420 & $=0.0001$ \\
\hline Acrosome reaction : & 0.532 & $<0.0001$ \\
\hline - r $=$ Correlation Coefficient & & $-\mathrm{P}<0.05=$ significance
\end{tabular}

Multiple stepwise regression analysis of androgen receptor expression and independent variables of semen parameters was done to determine which variables mostly affected by androgen receptor expression. The regression analysis revealed that acrosome reaction and linearity index were the most independent variables affected by androgen receptor expression (table 6).

Table (6): Multiple stepwise regression analysis of AR- expression and independent variables of semen parameters

\begin{tabular}{|l|l|l|}
\hline Variable & AR- expression \\
\hline & T & $\mathrm{P}$ \\
\hline Acrosome reaction & 5.233 & $<0.0001$ \\
\hline Linearity index & 2.130 & $=0.00364$ \\
\hline
\end{tabular}

\section{- $\mathbf{P}<\mathbf{0 . 0 5}=$ significance}




\section{DISCUSSION}

AR functions as a liganddependent transcription factor, regulating expression of an array of androgen-responsive genes. Androgen and the AR play important roles in male spermatogenesis and fertility ${ }^{(23)}$.

Several studies have raised the possibility that some germ cells may exhibit immunoreactive AR (24,25). Other reports point to Sertoli cells or Leydig cells or peritubular/myoid cells as the exclusive androgen target cells in the testis ${ }^{\text {(26-29)}}$. Interestingly, some previous studies have revealed that the AR expression in male germ cells is stage specific, only expressing in elongated spermatid at spermatogenic stage XI in rat testis ${ }^{(25)}$.

The presence of a functional AR in sperm at different levels: mRNA expression, protein expression and immunolocalization have been demonstrated. Also, it has been speculated that the importance of androgen in the sperm maturative process goes beyond the length of their life in seminiferous tubules, and continues when they became transcriptionally silent, through the AR nongenomic signaling (12). Furthermore, a significant amount of AR mRNA found in both X- and Ycarrier spermatozoa ${ }^{(30)}$.

The present study revealed that AR expression was significantly decreased in andrological diseases. Furthermore, AR expression was significantly correlated with grade A+B motility, velocity, linear velocity, $\alpha$ glucosidase and acrosome reaction of human spermatozoa. In fact, many authors explain the importance of $\mathrm{AR}$ expression on spermatogenesis and found that $A R$ actions are required for the formation of connections between Sertoli cells that make up the blood-testis barrier, maintaining the connections with haploid spermatid germ cells and the release of mature sperm from Sertoli cells (6,9,31-33). Handelsman, (34) identified that cell-specific ARmediated androgen actions in testis and in sex accessory glands is independent of testicular effects which are crucial for sperm maturation, motility and fertilizing ability. However, leucocytes, reactive oxygen species, cytokines, immunological abnormalities in patients with MAGI may play a role in the development of infertility ${ }^{(35)}$. It is widely believed that these mediators may be associated with the imbalance of antioxidants factors and appear to be responsible for specific molecular processes that particularly affect the motility of spermatozoa $^{(36)}$, and as a consequence this leads to decrease the expression of AR in that group of patients resulting in decrease in sperm function and infertility. These results are in agreement with report of Zalata et al. $^{(37)}$ who found that oxidative stress might be associated with WBC infiltration and abnormal sperm function detected by acrosin activity in particular.

As regards varicocele, it probably originates due to valvular absence or incompetence in the internal spermatic veins and may occur due to a number of different mechanisms, thus it is considered a multifactorial disease ${ }^{(38)}$. Also, it progressively leads to a decrease in semen quality and is 
associated to secondary infertility, probably because venous reflux and testicular temperature elevation induce testicular dysfunction. Varicocele also, associated with testicular hypoxia and increased oxidative stress causing alterations in sperm concentration, motility and morphology ${ }^{(39)}$. It has been found that varicocele is a significant risk factor for androgen deficiency that may influence AR expression in those patients, however repair may increase testosterone levels in men with varicocele $^{(40)}$.

Idiopathic male infertility is probably a heterogeneous collection of hypospermatogenic disorders, the possibility that inappropriate AR expression is indeed a causative factor in some cases of male infertility ${ }^{(33)}$. Kang et al. (41) reported that the inappropriate $\mathrm{AR}$ expression is due to polymorphism of the glutamine tract in the AR which can reduce receptor function and increase the risk of male infertility and defective spermatogenesis. Men whose AR has a polyglutamine tract length at the long end of the normal range have an increased incidence of impaired spermatogenesis and infertility. Dowsing et al $^{(\mathbf{4 2})}$ have proposed that longer polyglutamine tracts within the normal range increase the risk of impaired spermatogenesis in normal males indicating a direct relationship between the length of that AR-specific variable polymorphic region and defective sperm maturation caused by decreased functional competence of the AR.

In spite of numerous types of AR mutations, there is no significant correlation between the genotype mutation and phenotype manifestation. In fact, the phenotypes could even vary from the complete androgen insensitivity syndrome to oligozoospermia in a single mutation in one family ${ }^{(43)}$.

In the present study, the positive correlation between AR expression and sperm concentration and normal morphology could be explained by the report of Zhou et al. ${ }^{(3)}$ who proved the presence of AR in epididymal tissue and reported the importance of androgen in the completion of male gamete maturation during the epididymal transit. Also, Solakidi el al. ${ }^{\text {(10) }}$ verified the presence of AR in human sperm by western blot and by immunofluorescence assay in mitochondria and this could be related to the energy requirements of these cells and they suggested that the differential localization of AR in human sperm reveals distinct roles of these receptors in the physiology of sperm cells and, perhaps, also in the process of fertilization. O'Hara et al., ${ }^{(4)}$ concluded that epithelial AR signaling is essential for postnatal development and function of the epididymal epithelium and that disruption of this signaling can contribute to obstructive azoospermia.

In the present work, AR expression was positively correlated with testosterone meanwhile it was negatively correlated with FSH and $\mathrm{E}_{2}$. In fact, testosterone and AR are essential to maintain spermatogenesis and male fertility. In the absence of testosterone stimulation, spermatogenesis does not proceed beyond the meiosis stage. After withdrawal of testosterone, germ cells that have progressed beyond meiosis 
detach from supporting Sertoli cells and die, whereas mature sperm cannot be released from Sertoli cells resulting in infertility ${ }^{(\mathbf{4 5})}$. The classical mechanism of testosterone action is it activates gene transcription by causing the androgen receptor to translocate to and bind specific DNA regulatory elements. Also, testosterone has been found to act via two non-classical pathways in Sertoli cells. Testosterone stimulation can depolarize the Sertoli cell and cause calcium influx into Sertoli cells. Testosterone can also activate a series of kinases resulting in activation of the MAP kinase cascade and phosphorylation of the CREB transcription factor. The evidence accumulated suggests that classical and non-classical testosterone signaling contribute to the maintenance of spermatogenesis and male fertility ${ }^{(33)}$.

The present work revealed that acrosome reaction and linearity index by multiple regression analysis were the most independent variables affected by androgen receptor expression. Several compounds, such as sex steroids, are known to modulate the acrosomal exocytosis. Testosterone and AR regulates various functions in male reproductive physiology; however, little is known about the relationship between androgens and AR and the acrosome reaction. Further more, it has been found that testosterone exerts no inductor effects on the acrosome reaction of human spermatozoa ${ }^{(46)}$.

It could be concluded that the AR expression in a group of subfertile subjects correlated to poor sperm morphology and fertilizing potential. Better understanding of the regulation of AR expression from human spermatozoa might help to manipulate the fertilizing ability of spermatozoa for therapeutic benefits.

\section{REFERENCES}

1. Gray L. E., Ostby J., Furr J., Wolf C. J., Lambright C., Parks L., Veeramachaneni D. N., Wilson V., Price M., Hotchkiss, A., et al. (2001): Effects of environmental antiandrogens on reproductive development in experimental animals. Hum. Reprod. Update 7 (3): 248-264.

2. Zhang C., Yeh S., Chen Y-T., Wu C-C., Chuang K-H., Lin HY., Wang R-S., Chang Y-J., Mendis-Handagama C., Hu L., Lardy H., and Chang C.(2006): Oligozoospermia with normal fertility in male mice lacking the androgen receptor in testis peritubular myoid cells. Proc. Natl. Acad. Sci .,U S A. ,103(47): 17718-17723.

3. Zhou Q., Nie R., Prins G.S., Saunders P.T., Katzenellenbogen B.S., Hess R.A. (2002): Localization of androgen and estrogen receptors in adult male mouse reproductive tract. J. Androl., 23: 870-881.

4. Shumazaki S. (2002): The role of 5- $\alpha$ reductase in prostate disease and male pattern baldness. In: Chang $\mathrm{C}$, ed. Androgens and androgen receptor: mechanisms, functions and clinical applications. Norwell, MA: Kluwer Academic Publishers;Pp 155-196. 
5. Liao D .J. \& Dickson R. B. (2002): Roles of androgens in the development, growth, and carcinogenesis of the mammary gland. J. Steroid Biochem. Mol. Biol., 80:175-189.

6. Holdcraft R.W. and Braun R.E. (2004): Androgen receptor function is required in Sertoli cells for the terminal differentiation of haploid spermatids. Development 131:459-467

7. Heinlein C. A. \& Chang C. (2002): Androgen receptor (AR) coregulators: an overview. Endocr. Rev., 23:175-200.

8. Zhou X., Kudo A., Kawakami H., Hirano H. (1996): Immunohistochemical localization of androgen receptor in mouse testicular germ cells during fetal and postnatal development. Anat. Rec., 245:509-518

9. Wang R.S., Yeh S., Chen L.M., Lin H.Y., Zhang C., Ni J., Wu C.C., di Sant'Agnese P.A., DeMesy-Bentley K.L., Tzeng C.R., Chang C. (2006): Androgen receptor in Sertoli cell is essential for germ cell nursery and junctional complex formation in mouse testes. Endocrinology 147:5624-5633.

10. Solakidi S., Psarra A.M., Nikolaropoulos S., Sekeris C.E. (2005): Estrogen receptors $\alpha$ and $\beta$ (ER $\alpha$ and ER $\beta)$ and androgen receptor (AR) in human sperm: localization of ER $\beta$ and AR in mitochondria of the midpiece. Hum. Reprod ., 20:3481-3487

11. Pelletier G., Labrie C., Labrie F. (2000): Localization of estrogen receptor $\alpha$, estrogen receptor $\beta$ and androgen receptors in the rat reproductive organs. J. Endocrinol., 165:359-370.

12. Aquila S., Middea E., Catalano S., Marsico S., Lanzino M., Casaburi I., Barone I., Bruno R., Zupo S., Ando S. (2007): Human sperm express a functional androgen receptor: effects on PI3K/AKT pathway. Hum. Reprod., 22:2594-2605

13. McPhaul M.J. (1999): Molecular defects of the androgen receptor. J. Steroid Biochem. Mol. Biol., 69:315322.

14. World Health Organization (2010): WHO laboratory manual for the examination of human semen and sperm-cervical mucus interactions, 4th Ed. Cambridge, UK: Cambridge University Press.

15. Hinting A, Comhaire F, Schoonjans F.(1988): Capacity of objectively assessed sperm motility characteristics in differentiating between semen of fertile and subfertile men. Fertil. Steril. , 50(4):635-9.

16. Endtz, A.W. (1972) : A direct staining method for moist urinary sediment and moist human sperm]. Ned Tijdschr Geneeskd. 16(17):681-5.

17. Guerin J.F., Ali H.B., Rollet J., Souchier C. , and Czuba J.C . (1986) : $\boldsymbol{\alpha}$ - glucosidase as a specific epididymal enzyme markers its validity for the etiologic diagnosis of azoopermia , J . Androl., (1) : $156-162$.

18. Chomczynski, P. (1993): A reagent for the single-step simultaneous isolation of RNA, 
DNA and proteins from cell and tissue samples. Biotechniques 15(3): 536-537.

19. Raha, S., Ling, $M$. and Merante, F. (1998): Extraction of total RNA from tissues and cultured cells. In: Molecular Biomethods Handbook, Replay R, Walker JM (eds), Human Press Inc., Totowa, NJ.Ch.1:Pp.:1-8.

20. Hu, X.L., Liu, X.P., Lin, S.X., Deng, Y.C., Liu, N., Li, X. and Yao, L.B, (2004):NDRG2 expression and mutation in human liver and pancreatic Cancers. World J. Gastroenterol., 10(23):3518-3521.

21. Berchtold, M.W. (1989): A simple method for direct cloning and sequencing cDNA by the use of a single specific oligonucleotide and oligo (dT) in a polymerase chain reaction (PCR). Nucleic Acids Res., 17(1):453-461.

22. Schoonjans F., Zalata A., Depyudt C.E., and Comhaire F.H. (1995): MedCalc: a new computer program for medical statistics . Computer Methods and Programs in Biomedicine 48 : 257-262.

23. Wang R-S., Yeh S., Tzeng C-R., and Chang C. (2009): Androgen receptor roles in spermatogenesis and fertility: lessons from testicular cell-specific androgen receptor knockout Mice. Endocr. Rev. , 30(2): 119-132.

24. Kimura N., Mizokami A., Oonuma T., Sasano H., Nagura H. (1993): Immunocytochemical localization of androgen receptor with polyclonal antibody in paraffin- embedded human tissues. J. Histochem. Cytochem., 41:671678.

25. Vornberger W., Prins G., Musto N.A., Suarez-Quian C.A. (1994): Androgen receptor distribution in rat testis. ; new implications for androgen regulation of spermatogenesis. Endocrinology 134:2307-2316.

26. Ruizeveld de Winter J.A., Trapman J., Vermey M., Mulder E., Zegers N.D., van der Kwast T.H. (1991): Androgen receptor expression in human tissues: an immunohistochemical study. .J. Histochem. Cytochem.,39:927936.

27. Iwamura M., Abrahamsson PA., Benning C.M., Cockett A.T., Di Sant'Agnese PA. (1994): Androgen receptor immunostaining and its tissue distribution in formalin fixed, paraffin-embedded sections after microwave treatment. J Histochem. Cytochem. ,42:783788.

28. Goyal H.O., Bartol F.F., Wiley A.A., Neff C.W.( 1996): Immunolocalization of receptors for androgen and estrogen in male caprine reproductive tissues: unique distribution of estrogen receptors in efferent ductule epithelium. Biol. Reprod., 56:90101.

29. Suarez-Quian C.A., MartinezGarcia F., Nistal M., Regadera J. (1999): Androgen receptor distribution in adult human testis. J. Clin. Endocrinol. Metab., 84:350-358. 
30. Zuccarello D., Garolla A., Ferlin A, Menegazzo M., De Toni L., Carraro M., Veronese C., Foresta C. (2009): Androgen receptor is expressed in both $\mathrm{X}$ and Y-carrier human spermatozoa. Fertil. Steril., 91(1):193-200.

31. Chang C., Chen Y. T., Yeh S. D., Xu Q., Wang R. S., Guillou F., Lardy H., Yeh S. (2004): Infertility with defective spermatogenesis and hypotestosteronemia in male mice lacking the androgen receptor in Sertoli cells. Proc. Natl. Acad. Sci., USA 101: 6876-6881.

32. De Gendt K., Swinnen J.V., Saunders P.T., Schoonjans L., Dewerchin M., Devos A.,Tan K., Atanassova N., Claessens F., Lecureuil C., HeynsW., Carmeliet P., GuillouF., Sharpe R.M., Verhoeven G. (2004): A Sertoli cell-selective knockout of the androgen receptor causes spermatogenic arrest in meiosis. Proc. Natl. Acad. Sci., USA 101:1327-1332.

33. Walker W.H. (2010): Nonclassical actions of testosterone and spermatogenesis. Philos. Trans. R. Soc. Lond. B. Biol. Sci. , 365(1546): 1557-1569.

34. Handelsman D.J. (2009): Androgen physiology, pharmacology and abuse. In: De Groot LJ, Jameson JL, editors. Endocrinology. 6th edn. Philadelphia: Elsevier Saunders .Pp: 342-350.

35. Everaert K., Mahmoud A., Depuydt C., Maeyaert M., Comhaire F.(2003): Chronic prostatitis and male accessory gland infection--is there an impact on male infertility (diagnosis and therapy)? Andrologia 35(5):325-30.

36. Diemer T., Huwe P., Ludwig M., Hauck E.W., Weidner W. (2003): Urogenital infection and sperm motility. Andrologia 35(5):283-7.

37. Zalata A.A., Ahmed A.H., Allamaneni S.S., Comhaire F.H., Agarwal A.(2004): Relationship between acrosin activity of human spermatozoa and oxidative stress. Asian J. Androl. ,6(4):313-8.

38. French D.B., Desai N.R., Agarwal A.(2008): Varicocele repair: Does it still have a role in infertility treatment? Curr. Opin. Obstet. Gynecol. , 20:269-74.

39. Del Giudice P.T. , Lima S.B., Cenedeze M.A., Pacheco-Silva A., Bertolla R.P., Cedenho A.P. (2010): Expression of the Fasligand gene in ejaculated sperm from adolescents with and without varicocele .J. Assist. Reprod. Genet., 27:103-109.

40. Tanrikut C., Goldstein M., Rosoff J.S., Lee R.K., Nelson C.J., Mulhall J.P. (2011): Varicocele as a risk factor for androgen deficiency and effect of repair. BJU Int., 108 (9);1481 - 4.

41. Kang H-Y., Tsai M-Y., Chang C., Huang K-E. (2003): Mechanisms and clinical relevance of androgens and androgen receptor actions Chang Gung Med. J. (26) $6:$ 388-402.

42. Dowsing A.T., Yong E.L., Clark M., McLachlan R.I., de Kretser D.M., Trounson A.O.(1999): Linkage between male infertility 
and trinucleotide repeat expansion in the androgenreceptor gene. Lancet 354:640-3.

43. Chu J., Zhang R., Zhao Z., Zou W., Han Y., Qi Q., Zhang H., Wang J.C., Tao S., Liu X., Luo Z. (2002): Male fertility is compatible with an Arg (840) Cys substitution in the AR in a large Chinese family affected with divergent phenotypes of AR insensitivity syndrome. J. Clin. Endocrinol. Metab , 87:347-51.

44. O'Hara L., Welsh M., Saunders P.T., Smith L.B.(2011): Androgen receptor expression in the caput epididymal epithelium is essential for development of the initial segment and epididymal spermatozoa transit. Endocrinology 152(2):718-29.

45. Patrão M.T., Silva E.J., Avellar M.C. (2009): Androgens and the male reproductive tract: an overview of classical roles and current perspectives. Arq Bras Endocrinol. Metab. ,(53)8: 934 945.

46. Vigil P., Barrientos V.M., Vargas G.G., Machuca D.A., Cortés M.E.(2011): Assessment of the effect of testosterone on the acrosome reaction of human spermatozoa. Andrologia [Epub ahead of print]

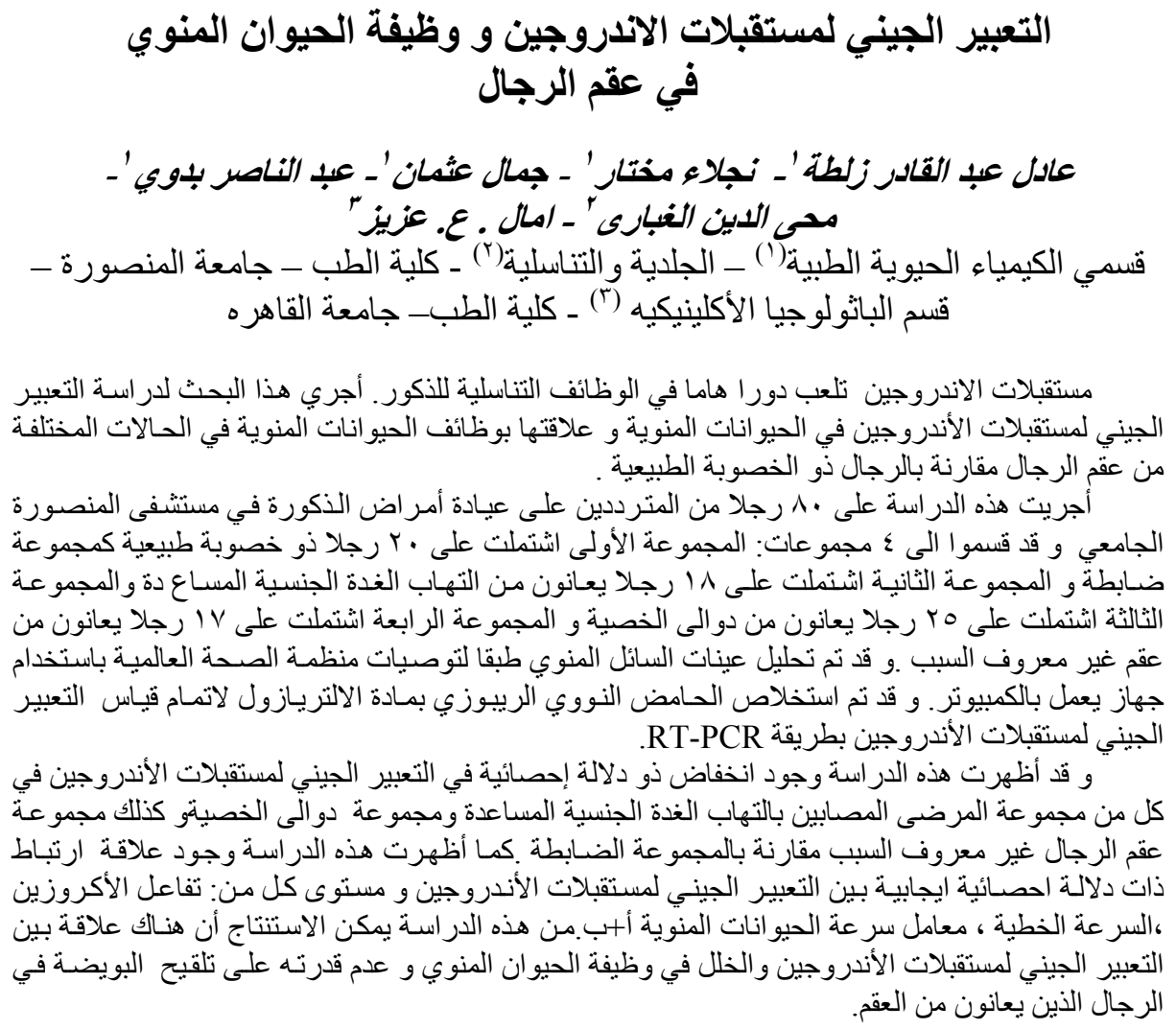

